\title{
Odpovědnost za jednání s péčí řádného hospodáře $z$ pohledu teorií právnických osob ${ }^{1}$
}

\section{Theoretical View on Liability for Acting with Due Managerial Care}

\author{
Lucie Novotná Krtoušová*
}

\begin{abstract}
Abstrakt
Občanský zákonik obsabuje povinnost člena statutárního orgánu jednat prì výkonu funkece s pécú rádného hospodáre a s jejím porušením spojuje mimo jiné povinnost nabradit právnické osobè skodu zpuisobenou pri výkonu funk.ce. Cílem tohoto článku je zodpovédèt otázku, zda členové statutárních orgánü právnických osob odpovidaji za jednáni s péč rádnébo hospodáre objektivně nebo subjektivné. Skutečnost, zda bude odpovédnost clenù statutárnich orgánů právnických osob chápána jako subjektivni či objektivní, je roz̧hodná z. hlediska posouzeni kritérii, na jejichž základè tyto osoby budou či nebudou povinny k nábradè škody. Autorka nejdrive pripominá právni úpravu odpovédnosti členu statutárnich orgánư obchodních společností pred rekodifikaci soukromého práva, která je potrebná pro pochopeni jádra současnébo sporu o koncepci odpovědnosti, a diskutuje dopady rekodifikace soukromého práva do oblasti právni úpravy postaveni členů statutárnich orgánu் a jejich odpovédnosti. Autorka zastává tezi, že pro vyréseni problému konstrukece soukromoprávni odpovědnosti za jednáni s pécu rádnébo hospodáre je treba se nejdruve zabývat otázkami, jake právnická osoba jedná, jak je jednáni právnické osoby ovlivnèno teoriemi právnickyich osob a jakým zpuisobem se teorie právnických osob projevují v platné právni úpravè, proto vènuje pozornost teoriím právnické osoby a jejich soućasnému nabliženi. Na tomto teoretickém základè se pak zabývá recentnimi rozporuplnými názory doktríny a judikatury na povahu zastoupení právnické osoby členem statutárníbo orgánu a odpovědnosti za jednáni s péči rádného hospodáre.
\end{abstract}

\section{Klíčová slova}

Člen statutárního orgánu; odpovědnost; péč rádnébo hospodáre; právnická osoba; zastoupení.

\begin{abstract}
The Civil Code lays down the duty of a governing body member to act with due managerial care in the discharge of their office. In case of breach of this duty governing body members are liable to the juristic person for any damage caused in the discharge of their office. The aim of this article is to analyse, whether liability for acting with due managerial of members of governing bodies of juristic persons is fault-based or strict. The question of whether liability of members of juristic persons' governing bodies is concieved as fault-based or strict liability is then decisive in terms of the criteria based on which these persons will or will not be liable.
\end{abstract}

* Mgr. Lucie Novotná Krtoušová, Ph.D., Katedra teorie práva a právních učení, Právnická fakulta, Univerzita Karlova, Praha; asistentka soudce, Krajský soud v Ústí nad Labem - pobočka Liberec / Department of Legal Theory and Legal Doctrines, Faculty of Law, Charles University, Prague; Legal Assistant, Regional Court in Ústí nad Labem - office Liberec, Czech Republic / E-mail: lucie.krtousova@ seznam.cz

1 Tento článek byl zpracován v rámci projektu Grantové agentury České republiky reg. č. 16-22016S „Právní jednání a odpovědnost právnických osob“. 
The author recalls first the legal regulation of liability of members of companies' governing bodies which applied before the recodification of private law and which is necessary for understanding the core of the current dispute on the concept of liability, and discusses the impact of the recodification of private law on the provisions governing the position of governing body members and their liability. The author outlines the thesis that, to resolve the issue of liability for a breach of due managerial care, it is first necessary to answer the questions of how a juristic person acts, how acts of a juristic person are influenced by various theories of juristic persons, and in what way these theories are manifested in the applicable law; therefore, she deals with the theories of juristic persons and their recent understanding. On this theoretical basis she discusses the recent contradictory views in jurisprudence and case-law on the nature of representation of a juristic person by a governing body member and the nature of liability for acting with due managerial care.

\section{Keywords}

Due Managerial Care; Juristic Person; Liability; Member of Governing Bodies; Representation.

\section{Úvod}

Tento článek si klade otázku, zdali členové statutárních orgánů právnických osob odpovídají za jednání s péčí řádného hospodáře objektivně, anebo na základě svého zavinění, tj. subjektivně. K zodpovězení nastíněných otázek nejdříve zobrazím posuny v chápání zažitých pojmů, které prínesla rekodifikace soukromého práva. Z toho vyplynuvší problém koncepce odpovědnosti členů statutárních orgánů se pokusím zodpovědět za pomoci teorií právnických osob. Budu argumentovat, že teoretický spor o podstatu právnické osoby má význam i v dnešním právu, byt' se těžiště významu přesouvá na poněkud nižší úroveň, úroveň řešení konkrétních právních otázek, které s konstrukcí právnické osoby souvisejí.

Otázka, zda je konstrukce právnické osoby postavena na teorii fikce či teorii reality vůbec není planým teoretizováním, nýbrž jde o to, jaký odpovědnostní režim budou mít členové statutárních orgánů za jednání s péči řádného hospodáře. V případě, že člen statutárního orgánu má postavení zákonného zástupce, lze uvažovat o tom, že povinnosti, které se na něj vztahují, jsou dány zákonem, a tedy i jejich porušení lze subsumovat pod zákonnou odpovědnostní skutkovou podstatu založenou na subjektivním principu. V př́padě, že budeme považovat člena statutárního orgánu za zástupce na základě smlouvy či zástupce sui generis, lze uvažovat o tom, že odpovědnost za jednání s péči rádného hospodáře podřadíme pod smluvní odpovědnostní skutkovou podstatu, za kterou se odpovídá objektivně.

\section{Rekodifikační posuny v chápání zažitých právních pojmů}

Rekodifikace soukromého práva prinesla do oblasti právní úpravy postavení členů statutárních orgánů a jejich odpovědnosti řadu výrazných změn. Předně občanský zákoník²

2 Zákon č. 89/2012 Sb., občanský zákoník, ve znění pozdějších předpisů (dále jen „obč. zák.“ nebo „občanský zákoník“). 
a zákon o obchodních korporacích ${ }^{3}$ stojí na antropocentrickém pojetí a odmítají antropologizaci právnických osob a berou za své hledisko, že právnické osoby jsou umělé útvary, které jsou vytvořeny proto, aby sloužily zájmům člověka. ${ }^{4}$ Právnická osoba není schopna sama právně jednat, a zákon proto předpokládá, že vưli za ni nahrazují její orgány (〔 151 odst. 1 obč. zák.). Zákon dále stanoví, že za právnickou osobou jednají zpravidla její statutární orgány, a to jako zástupci (『 436 a násl. obč. zák.), nikoliv jako nástroje přímého jednání samotné právnické osoby. Za předchozí úpravy ${ }^{5}$ člen statutárního orgánu nebyl zástupcem právnické osoby, v prépadě jednání statutárního orgánu se jednalo o přímé jednání právnické osoby. Současná právnická literatura a judikatura není jednotná ohledně otázky povahy zastoupení právnické osoby členem statutárního orgánu, když se dovozuje jak povaha zastoupení smluvního, tak zákonného, nebo suigeneris.

Pro pochopení jádra sporu o koncepci odpovědnosti členů statutárních orgánů právnických osob je nutné si připomenout právní úpravu odpovědnosti členů statutárních orgánů obchodních společností před rekodifikací soukromého práva. Otázka povinností a odpovědnosti členů statutárních orgánů byla řešena pouze obchodním zákoníkem. Obecné ustanovení o povinnostech členů statutárních orgánů a jejich odpovědnosti v obchodním zákoníku nebylo zakotveno a nacházíme až speciální úpravu ve vztahu k představenstvu akciové společnosti v \194 odst. 5 obch. zák., která obsahovala základní ustanovení o povinnosti péče řádného hospodáře členů představenstva. ${ }^{6}$

Dobově převládalo pojetí, že vztah mezi členem statutárního orgánu a obchodní společností má povahu absolutního obchodního závazkového vztahu dle \261 odst. 3 písm f) obch. zák. ${ }^{7}$ Obchodní zákoník upravoval v \373 a násl. výslovně odpovědnost za škodu způsobenou porušením povinností z obchodních závazkových vztahů. Podle \757 obch. zák. se vztahovala tato úprava také na př́pady porušení povinností stanovených obchodním zákoníkem. Podle úpravy obchodního zákoníku nebylo třeba řešit problém, zda jde o subjektivní, nebo objektivní odpovědnost, jednak proto, že se takto neodlišovalo mezi porušením smlouvy a zákona, a jednak i pro dikci $\int 757$ obch. zák., který porušení zákona vždy podřazoval porušení smlouvy. Odpovědnost za porušení péče řádného

3 Zákon č. 90/2012 Sb., o obchodních společnostech a družstvech (zákon o obchodních korporacích), ve znění pozdějších předpisů (dále jen „z. o. k.“ nebo „zákon o obchodních korporacích“).

4 ELIÁŠ, K. Nový občanský zákoník s aktualizovanou diovodovou zprávou a rejstř́kem. Ostrava: Sagit, 2012 , s. 77.

5 Zákon č. 40/1964 Sb., občanský zákoník, ve znění pozdějších předpisů (dále jen „OZ 1964“ nebo „občanský zákoník 1964“); zákon č. 513/1991 Sb., obchodní zákoník, ve znění pozdějších předpisů (dále jen „obch. zák.“ nebo „obchodní zákoník“).

6 Úprava byla aplikována také na členy dozorčí rady ( $\int 200$ odst. 3 obch. zák.), jednatele společností s ručením omezeným (\$ 135 odst. 2 obch. zák.) a dozorčí radu této formy společnosti (\$ 138 odst. 2 obch. zák.) a také na jejich faktické vedoucí (\66 obch. zák.) a likvidátory (srov. usnesení Nejvyššího soudu ze dne 3. 5. 2007, sp. zn. 5 Tdo 433/2007).

7 ČERNÁ, S. Obchodni právo. Akciová společnost. 3. díl. Praha: ASPI, 2006, s. 247. 
hospodáře byla odpovědností objektivní, tedy neuplatňovalo se zde hledisko, zda člen statutárního orgánu obchodní společnosti toto porušení zavinil, nebo ne. ${ }^{8}$ Nejvyšší soud judikoval, že péče řádného hospodáře není vystavena na odpovědnosti za výsledek, ale za správný proces rozhodování, jinak řečeno, za jednání lege artis. ${ }^{9}$ Nešlo o odpovědnost absolutní, protože obchodní zákoník připouštěl liberaci prokázáním okolností vylučujících protiprávnost ${ }^{10}$. Na jiné typy právnických osob se ovšem úprava $\mathrm{v}$ obchodním zákoníku aplikovat prímo nedala, občanský zákoník o odpovědnosti členů statutárních orgánů právnických osob mlčel.

Základní úpravu povinností členů statutárních orgánů právnických osob po rekodifikaci soukromého práva je třeba hledat v \159 odst. 1 obč. zák., který stanoví, že kdo přijme funkci člena statutárního orgánu právnické osoby, zavazuje se, že ji bude vykonávat s péči rádného hospodáře, jež je vymezena jako povinnost vykonávat funkci s nezbytnou loajalitou i s potřebnými znalostmi a pečlivostí. Dále je v tomto ustanovení stanovena vyvratitelná právní domněnka, že jedná nedbale ten, kdo není této péče řádného hospodáře schopen, ač to musel zjistit při prrijetí funkce nebo při jejím výkonu, a nevyvodí z toho pro sebe důsledky. Koncepce, kterou zvolil občanský zákoník na rozdíl od předcházející úpravy, formuluje zastřešující povinnost péče ráádného hospodáře a $\mathrm{v}$ rámci ní rozlišuje mezi povinností loajality a povinností užívat při výkonu funkce potřebné znalosti a pečlivost. I přes jednotlivé názory, které se hlásí k zužujícímu výkladu osobní působnosti péče řádného hospodáře, ${ }^{11}$ zastávám názor, že zákonodárce formuloval koncept péče řádného hospodáře jako pojem zastřešující nejen všechny př́pady, kdy člen voleného orgánu spravuje záležitosti právnické osoby, ale i prŕípady jakéhokoliv jednání při správě cizího majetku. ${ }^{12}$ Ve vztahu k veřejnoprávním korporacím je však nutné péči řádného hospodáře aplikovat nikoliv paušálně, ale diferencovaně, a to, neexistuje-li speciální úprava vyššího standardu péče a zároveň pokud se to slučuje s právní povahou

8 ŠTENGlOVÁ, I. In: ŠTENGLOVÁ, I., S. PLÍVA, M. TOMSA a kol. Obchodni qákoník: Komentár. 13. vyd. Praha: C. H. Beck, 2010, s. 1038.

9 Rozsudek Nejvyššího soudu ze dne 10. 11. 1999, sp. zn. 29 Cdo 1162/99; rozsudek Nejvyššího soudu ze dne 30. 3. 2011, sp. zn. 29 Cdo 4276/2009; usnesení Nejvyššího soudu ze dne 23. 11. 2005, sp. zn. 5 Tdo 1143/2005, publikované pod č. 5432/2005 Sbírky soudních rozhodnutí a stanovisek.

10 ŠTENGlOVÁ, I. In: ŠTENGLOVÁ, I., S. PLÍVA, M. TOMSA a kol. Obchodni qákoník: Komentár. 13. vyd. Praha: C. H. Beck, 2010, s. 1038.

11 SVEJKOVSKÝ, J. In: SVEJKOVSKÝ, J. a kol. Právnické osoby v novém občanském zákoníku: komentár. Praha: C. H. Beck, 2013, s. 79; LÁLA, D. Povaha členství ve statutárním orgánu osobní společnosti aneb je člen statutárního orgánu osobní společnosti členem voleného orgánu ve smyslu občanského zákoníku? Obchodnèprávní revue, 2018, s. 106 a násl.

12 Shodně PIHERA, V. a B. HAVEL. Povaha funkce a odpovědnost členů orgánů obchodních společností jako východisko racionálního corporate governance. Práuní roz̧bledy, 2019, č. 23-24, s. 836 a násl.; BORKOVEC, A., L. JOSKOVÁ a P. TOMÁŠEK. Fiduciární vztah a fiduciární povinnost pohledem (nejen) zahraničních jurisdikcí. Prámí roz̧ledy, 2018, č. 23-24, s. 815 a násl. 
těchto osob. ${ }^{13}$ Havel prrináší př́klad diferencované aplikace péče řádného hospodáře na př́íkladu orgánů obce, kdy dovozuje aplikaci na starostu či primátora, na rozdíl od členů zastupitelstva s ohledem na odlišný způsob ustavení do funkce. ${ }^{14}$

Stávající občanský zákoník stejně jako předchozí právní úprava speciální skutkovou klauzuli odpovědnosti členů statutárních orgánů nezná. ${ }^{15}$ Z toho vyplývá, že je nutné stavět jenom na obecné úpravě odpovědnosti. Občanský zákoník opustil doktrínu jednotného civilního deliktu a upravuje odlišný režim povinnosti nahradit škodu v důsledku porušení zákonné povinnosti v \2910 a násl. či smluvní povinnosti v \2913 a násl. Nová úprava se tak viditelně odchyluje od koncepce generálního deliktu v \420 OZ 1964. Z textu je zjevná inspirace německou úpravou $\int 823 \mathrm{BGB}^{16}$, kterou se netají ani důvodová zpráva. ${ }^{17} \mathrm{~V}$ komentářové literatuře je sporné, zda se v př́padě odpovědnosti za jednání s péčí řádného hospodáře jedná o povinnost smluvní, jejî̌ porušení zakládá odpovědnost objektivní, či povinnost zákonnou, jejíž porušení zakládá odpovědnost subjektivní.

Další koncepční změnou je, že občanský zákoník opouští v českém diskursu tradiční sankční pojetí odpovědnosti a přiklání se jejímu preventivnímu a prospektivnímu pojetí. ${ }^{18}$ Koncepční rozpor spočívá v přesné definici předpokladů vzniku právní odpovědnosti, nejčastěji o přesné určení, zdali se odpovídá již za dodržení primární právní povinnosti (např. ze zákona či ze smlouvy), nebo až za její porušení. Rozdíl těchto dvou pojetí spočívá také v tom, zda spojují právní odpovědnost jen se vznikem sekundární povinnosti (sankční pojetî), nebo s jakoukoliv sankcí za porušení právní povinnosti (prospektivní pojetî). ${ }^{19}$ Pojetí odpovědnosti jako občanskoprávní sankce (retrospektivní, následné, sankční pojetí) spočívá v tom, že se odpovědnost rozpadá do dvou fází: fáze latentní

13 HAVEL, B. In: MELZER, F. Občanský quákoník: velký komentár. Sv. 1, 』 1-117. Praha: Leges, 2013, s. 273; souhlasně BEZOUŠKA, P. a L. PIECHOWIZOVÁ. Nový občanský zákoník. Nejdưležitějši zmèny. Olomouc: ANAG, 2014, s. 49; LASÁK, J. In: LAVICKÝ, P. a kol. Občanský zuákoník I. Obecná cáast. (§ 1-654). Komentár. Praha: C. H. Beck, 2014, s. 817; odlišně pro veřejný ústav BERAN, K. Právnické osoby verejného práva. Praha: Linde, 2006, s. 102.

14 HAVEL, B. Komercializace právnických osob? (k použití pravidla podnikatelského úsudku nejen ve světě fundací). Právník, 2015, č. 11, s. 949.

15 Podmíněná formulace zákonného ručení \ 159 odst. 3 obč. zák. předpokládá, že členovi orgánu vznikla povinnost hradit škodu, která by měla vyplývat z jiných ustanovení. Stejně např́klad předpokládá úprava reflexní škody v \ 213 obč. zák. návaznost na př́pad, kdy člen orgánu korporace poškodí korporaci, avšak nezakládá povinnost $\mathrm{k}$ náhradě škody, a mohli bychom nalézt další př́klady z občanského zákoníku i zákona o obchodních korporacích.

16 Bürgerliches Gesetzbuch (německý občanský zákoník) (dále jen "BGB").

17 ELIÁŠ, K. Nový občanský zákoník s aktualizovanou dìvodovou zppávou a rejstř́kem. Ostrava: Sagit, 2012, s. 1022 a 1030 .

18 Ibid., s. 79.

19 KNAPPOVÁ, M. Povinnost a odpovédnost v občanském právu. Praha: Academia, 1968, s. 166 a 167 ; KNAPP, V. Teorie práva. Praha: C. H. Beck, 1995, s. 201; GERLOCH, A. Teorie práva. 6., aktualiz. vyd. Plzeň: Vydavatelství a nakladatelství Aleš Čeněk, 2013, s. 162; podrobně JANEČEK, V. Kritika právní odpovědnosti. Praha: Wolters Kluwer, 2017, s. 85 a násl. 
a následně do fáze aktivizace odpovědnosti. Latentní fáze odpovědnosti vzniká současně se vznikem povinnosti v podobě hrozby sankcí, teprve porušením této povinnosti se latentní odpovědnost aktivizuje. ${ }^{20}$ Podle tohoto pojetí tedy vzniká odpovědnost teprve tehdy, byla-li povinnost porušena, a toliko tehdy, má-li porušení povinnosti za následek dopadnutí sankce. ${ }^{21}$ Preventivní pojetí odpovědnosti rozšiřuje odpovědnost i do latentní fáze hrozby sankcí, která existuje před samotným porušením povinnosti. ${ }^{22}$ Za převládající přístup v české poválečné civilistice bylo považováno sankční pojetí právní odpovědnosti. ${ }^{23} \mathrm{~V}$ pozdějších dílech i zastánce preventivního pojetí Knapp dochází k syntéze, když tvrdí, že nejvýraznějším a typickým případem odpovědnosti je povinnost k náhradě škody v důsledku porušení povinnosti. ${ }^{24}$

Občanský zákoník z roku 1964 užíval pojem odpovědnost zejména ve smyslu civilní sankce za protiprávní jednání, byt' ani tento kodex nebyl terminologicky důsledný. ${ }^{25}$ Nový občanský zákoník se terminologicky snaží od tohoto pojetí odklonit, proto namísto pojmu odpovědnost používá pojem povinnost, a to ve všech významových rovinách, ${ }^{26}$ avšak je v této proklamované snaze o dogmatickou a terminologickou jednotnost stejně nedůsledný, jako byl občanský zákoník z roku $1964 .{ }^{27}$ Nadto pojem odpovědnosti takto dogmaticky v českém právu chápat nelze, zvláště když nap̌r. pojmy subjektivní a objektivní odpovědnost nevyjadřují vztah k sankci, ale jsou pojmem pro povinnost k náhradě škody s ohledem nebo bez ohledu na zavinění, tedy jako terminus technicus vyjadřují

20 KNAPPOVÁ, M. Povinnost a odpovédnost v občanském právu. Praha: Academia, 1968, s. 166 a 172.

21 Ibid., s. 167 a 168.

22 KNAPP, V. Některé úvahy o odpovědnosti v občanském právu. In: Stát a právo, Praha: Nakladatelství Československé akademie věd, 1956, č. I, s. 66 a násl.

23 KNAPPOVÁ, M. Povinnost a odpovédnost v občanském právu. Praha: Academia, 1968, s. 166 a 167; LUBY, Š. Prevencia a zodpovednost'v občianskom práve. I. Bratislava: Vydavatel'stvo Slovenskej akadémie vied, 1958, s. 43; ŠVESTKA, J. Odpovédnost za škodu podle ob̌́anského zákoníku. Praha: Academia, 1966, s. 37; OVEČKOVÁ, O. Zodpovednost'v hospodárskom práve. Bratislava: Veda, 1983, s. 183; zastáncem preventivního pojetí odpovědnosti KNAPP, V. Některé úvahy o odpovědnosti v občanském právu. In: Stát a právo, Praha: Nakladatelství Československé akademie věd, 1956, č. I, s. 66 a násl.

24 KNAPP, V. Teorie práva. Praha: C. H. Beck, 1995, s. 201.

25 MELZER, F. In: MELZER, F. a kol. Občanský zákoník: velký komentár. Svazek I. \1-117. Praha: Leges, 2013, s. 318.

26 HRÁDEK, J. In: ŠVESTKA, J., J. DVOŘÁK, J. FIALA a kol. Občanský quákoník: komentár. Sv. VT. (』 2521 až 3081). Praha: Wolters Kluwer ČR, 2014, s. 861; také občanský zákoník je však v tomto rozlišení nedůsledný, srov. MELZER, F. In: MELZER, F. a kol. Občanský zákoník: velký komentár. Svazek I. \1-117. Praha: Leges, 2013, s. 318.

27 V občanském zákoníku lze setkat s pojetím odpovědnosti ve smyslu primární povinnosti (\ 193, 1190 či 2161 návrhu), ve smyslu následku porušení povinnosti (\$ 2542, \ 2543 či \ 1935 obč. zák.), ve významu následku protiprávního stavu (\ 1288 či \ 1625 obč. zák.) i v dalších významech (\$ 24 a \ 420 obč. zák.). Sankční význam odpovědnosti je navíc často nezbytné dovodit poměrně složitým zpo̊sobem (viz $\int 2543$ odst. 1 obč. zák.). Srov. PRAŽÁK, P. Má institut právní odpovědnosti v návrhu nového občanského zákoníku jasnou koncepci? Právní roz̧bledy, 2012, č. 3, s. 101 a násl. 
charakter určitého závazku mezi škůdcem a poškozeným. ${ }^{28}$ Smyslem péče řádného hospodáře není, aby vznikla povinnost k náhradě škody v důsledku jejího porušení, nýbrž naopak aby se osoby v pozici, kdy je jim tato povinnost uložena, chovaly tak, aby jim sekundární povinnost k náhradě škody nevznikla. Jinými slovy, jde o pojetí, které neřeší odpovědnost (jakožto sankci), nýbrž naopak jako pozitivní povinnost. Z tohoto hlediska lze v prŕpadě této povinnosti uvažovat spíše o prospektivní koncepci odpovědnosti, jakožto odpovědnosti, která se realizuje tím, že se osoba chová rádně, tj. v souladu s požadavky které jsou na ni kladeny v návaznosti na výkon její funkce.

Ve světle rekodifikačních změn soukromého práva je třeba tedy vyjasnit, zdali členové statutárních orgánů právnických osob odpovídají objektivně, anebo na základě svého zavinění, tj. subjektivně. Odpověd’ na tuto otázku je v české právní doktríně nejednotná, přičemž existují dobré argumenty jak pro první, tak pro druhé řešení. Skutečnost, zdali budeme chápat odpovědnost členů statutárních orgánů právnických osob jako subjektivní či objektivní, je v první řadě rozhodná z hlediska posouzení kritérií, na jejichž základě tyto osoby budou či nebudou povinny k náhradě škody. $\mathrm{V}$ prípadě, že budeme chápat odpovědnost člena statutárního orgánu jako objektivní, znamená to, že zavinění zde nehraje roli, a jde jen o to, zdali dotyčná osoba porušila či neporušila stanovené kritérium péče řádného hospodáře, které může být eventuálně zmírněno privilegiem podnikatelského úsudku. Je ovšem možné, aby se tato osoba své povinnosti k náhradě škody zprostila na základě liberačních důvodů. Pokud budeme odpovědnost považovat za subjektivní, potom je protiprávnost pouhým předpokladem k dalšímu kroku, který spočívá v odpovědi na otázku, zdali škoda byla či nebyla dotyčnou osobou zaviněna.

Varianta, že členové statutárních orgánů odpovídají objektivně, je založena na konstrukci, že vztah člena statutárního orgánu a právnické osoby je vztahem smluvním, proto také člen statutárního orgánu - jakožto fyzická osoba - odpovídá právnické osobě objektivně na základě smluvní odpovědnostní skutkové podstaty podle \2913 obč. zák. Druhá možná konstrukce, jež chápe odpovědnost člena orgánu právnické osoby jako odpovědnost subjektivní, je založena na úvaze, že důvodem vzniku této odpovědnosti není smlouva, nýbrž zákon sám. V okamžiku, kdy se členové statutárního orgánu ocitnou ve své funkci, at' už se tak stane z jakéhokoliv důvodu, jsou povinni na základě zákona dodržovat péči řádného hospodáře, kterou jim zákon ukládá. Z toho důvodu jde o odpovědnost na základě zákonné odpovědnostní skutkové podstaty podle \ 2910 obč. zák., což znamená, že k jejímu vzniku je nutné vedle protiprávního jednání také zavinění na straně škůdce, tj. fyzické osoby v pozici člena statutárního orgánu.

Teoretická konstrukce právnické osoby navazující na teorie právnických osob je důležitá proto, aby bylo možné posoudit, jaké postavení zaujímá statutární orgán právnické osoby a jaké účinky má tedy i jednání fyzické osoby v pozici člena statutárního orgánu právnické

28 HRÁDEK, J. In: ŠVESTKA, J., J. DVOŘÁK, J. FIALA a kol. Občanský quákoník: komentár. Sv. VT. (J 2521 a气̌ 3081). Praha: Wolters Kluwer ČR, 2014, s. 861. 
osoby. Pozornost, která se v doktríně vztahuje k právnickým osobám, je obvykle zaměřena na jejich právní jednání a v tom se také projevuje vliv teorií právnických osob, méně se již projevuje a diskutuje v konstrukci deliktní způsobilosti právnické osoby. Tato úvaha přitom vưbec není planým teoretizováním, nýbrž jde o to, jaký odpovědnostní režim budou mít členové statutárních orgánů za jednání s péčí řádného hospodáře. V prípadě, že člen statutárního orgánu má postavení zákonného zástupce, lze uvažovat o tom, že povinnosti, které se na něj vztahují, jsou dány zákonem, a tedy i jejich porušení lze subsumovat pod zákonnou odpovědnostní skutkovou podstatu založenou na subjektivním principu. $\mathrm{V}$ př́padě, že budeme považovat člena statutárního orgánu za zástupce na základě smlouvy či zástupce sui generis, lze uvažovat o tom, že odpovědnost za jednání s péči řádného hospodáře podřadíme pod smluvní odpovědnostní skutkovou podstatu, za kterou se odpovídá objektivně. Pro vyřešení nastíněného problému konstrukce soukromoprávní odpovědnosti za jednání s péčí řádného hospodáře je tedy třeba se nejdříve zabývat otázkami, co je to z teoretického pohledu statutární orgán právnické osoby, jak právnická osoba jedná, jak je jednání právnické osoby ovlivněno teoriemi právnických osob a jakým zpo̊sobem se teorie právnických osob projevují v platné právní úpravě.

\section{Obživlý spor o teoretickou podstatu právnické osoby}

Pojem a podstata právnické osoby jsou více než 100 let předmětem sporu. Kontroverze začala rozdílností romanistické teorie fikce (Fiktionstheorie) a germanistické teorie reálné svazové osobnosti (Theorie der realen Verbandspersönlichkeit). Tradičně je vysvětlováno učení Savignyho tak, že v návaznosti na Kantův kategorický imperativ ${ }^{29}$ popřel realitu právnické osoby a považoval je za pouhé pozitivně právní fikce. ${ }^{30}$ Hledání skutečných a fikcí právnické osoby zakrytých nositelů práv a povinností vyústilo v řadu dalších teorií navazujících na teorii fikce. ${ }^{31}$ Opačná pozice vytvořená Gierkem vyzvedává v protikladu k teorii fikce skutečnou existenci právnické osoby jako reálné svazové osobnosti, ${ }^{32}$ a našla také své následovníky. ${ }^{33}$

Za nejstarší teorii právnických osob, která je bezprostředně spojena i se samotným pojmem právnické osoby, můžeme považovat právě teorii fikce. ${ }^{34}$ Savigny, autor teorie fikce i moderního pojmu právnické osoby, vycházel z toho, že původní pojem osoby nebo

29 KANT, I. Základy metafyzikey mravio. 2. vyd. Praha: Svoboda, 1990, s. 91 a 97.

30 SAVIGNY, F. C. von. System des heutigen Römischen Rechts. Zweyter Band. Berlin: Veit \& Comp., 1840, s. 236 a násl. Je třeba poznamenat, že označení Savigniho učení jako teorie fikce je značně zjednoušující a vedoucí $\mathrm{k}$ nedorozumění a bylo vytvořeno nikoliv jím, ale zastánci teorie reality.

31 Pro podrobný přehled v češtině srov. BERAN, K. Pojem osoby v právu: (osoba, morální osoba, právnická osoba). Praha: Leges, 2012, s. 69 a násl.

32 GIERKE, O. von. Genossenschaftstheorie und die deutsche Rechtsprechung. Berlin, 1887, s. 350 a násl.

33 Pro podrobný přehled v češtině srov. BERAN, K. Pojem osoby v právu: (osoba, morálni osoba, právnická osoba). Praha: Leges, 2012, s. 74 a násl.

34 Ibid., s. 66 a násl. 
právního subjektu musí spadat v jedno s pojmem člověka, když si položil otázku, ,[k] do mi̊re být nositelem nebo subjektem právního vatabu? Tato otázka se týká potenciálního ,mèti" práva nebo právni zpiisobilosti [...]. Proto musi puivodni pojem osoby nebo právního subjektu spadat v jedno s pojmem clověka a tato piovodni identita obou pojmu může být vyjádrena následujici formuli: každý (jednotlivý) clověk a pouze (jednotlivý) clověk je právně zpuisobilý. "35 Uznal však také, že právní subjektivita může být rozšířena na umělé, jako pouhé fikce přijímané, subjekty, a „takový subjekt nazval právnickou osobou, tj. osobou, která byla vytvoŕena pouze za práuními účely. "36

Savigny vymezuje právnickou osobu jako „umèle vytvorený majetkoprávnè zpuisobilý subjekt. “37 Nabytí majetkového práva však předpokládá právní jednání, kterého je schopen dle Savignyho pouze člověk: „Sama jednáni však predpokládaji myslici a chtějici bytost, jednotlivého člověkea, cožprávnické osoby jako poubé fikece nejsou, a proto zde vzniké vnitrni rozpor majetkově zpuisobilého subjek.tu, který však nemưze splnit podminky k.jeho nabytí. "38 Všude tam, kde se tento rozpor nachází (tj. např. i u nesvéprávných osob), musí být vyřešen pomocí umělého institutu zastoupení. Teorie fikce tak podle Savignyho není založena na tom, že by právnická osoba měla fiktivní vůli, nýbrž na tom, že jednání fyzických osob (a tedy jejich vưle) se považuje za jednání právnické osoby, a právě v tom spočívá ona fikce. Proto také právnická osoba vưli nemá, a je ji tak třeba nejspíše přirovnat $\mathrm{k}$ nesvéprávnému a jejího zástupce $\mathrm{k}$ opatrovníkovi. ${ }^{39}$ Lze tedy shrnout, že podle teorie fikce lze zjednodušeně řečeno konstatovat, že právnická osoba není způsobilá k vlastnímu právnímu jednání, nebot' sama o sobě neexistuje, a tedy ani nemá vlastní rozum a vưli. Fikce právnické osoby tak spočívá právě v tom, že se za vůli právnické osoby považuje rozum a vưle člověka, který za tuto právnickou osobu jedná. Za právní jednání právnické osoby považuje teorie fikce jednání reálného člověka a přitom k tomu dodává, že toto jednání lze považovat za jednání právnické osoby pouze na základě fikce, nebot' stále jde jen o jednání tohoto určitého konkrétního člověka. ${ }^{40}$ Teorie organická (tj. teorie reálné svazové osobnosti), jejímž nejvýznamnějším reprezentantem je Gierke, vychází z předpokladu, že svazová osoba (Verbandsperson) jako taková existuje ještě předtím, než ji právo uzná. Proto také Gierke hovoří o tzv. duchovním organismu, který se projevuje tím, že má vlastní samostatnou vůli, kterou je způsobilý projevovat navenek. Proto Gierke soudí, že: „... všude tam, kede se ukážze svazová osoba, vyvstává pro právni védu úloha práunimi normami uchopit, usporádat a rozvijet vnitřni a vnèjsí svazový život jako výraz tělesně duchouni životni jednotky společenského organismu. "41 Shrňme tedy, že konstrukce právního jednání právnické osoby založená na organické teorii znamená,

35 SAVIGNY, F. C. von. System des heutigen Römischen Rechts. Zweyter Band. Berlin: Veit \& Comp., 1840, s. 2.

36 Ibid., s. 236.

37 Ibid., s. 240.

38 Ibid., s. 282.

39 SAVIGNY, F. C. von. System des heutigen Römischen Rechts. Zweyter Band. Berlin: Veit \& Comp., 1840, s. 312.

40 BERAN, K. Pojem osoby v právu: (osoba, morálni osoba, právnická osoba). Praha: Leges, 2012, s. 74 a násl.

41 GIERKE, O. von. Das Wessen der Menschlichen Verbände. Berlin, 1902, s. 27. 
že právnická osoba je organismem, jehož některé orgány její rozum a vưli tvoří a jiné zase projevují. Člověk, který jedná jako orgán právnické osoby, ve chvíli, kdy jedná jako orgán, vlastně není sám o sobě žádnou osobou, je jen jakýmsi médiem, jehož prostřednictvím právnická osoba jako vyšší duchovní organismus projevuje svoji vůli. ${ }^{42}$

Jak už jsem naznačila $\mathrm{v}$ úvodu, teoretická koncepce právnické osoby v občanském zákoníku z roku 1964 byla založena na organické teorii. Tento závěr je možné opřít o znění \ 18 odst. 1 OZ 1964, který přiznával právnickým osobám způsobilost mít práva a povinnosti a v \19a odst. 1 OZ 1964 bylo stanoveno, že způsobilost právnické osoby nabývat práva a povinnosti může být omezena jen zákonem. Skutečnost, že právnická osoba byla považována za osobu svéprávnou mající vlastní vưli, plynula nejen z \ 20 odst. 1 OZ 1964, který stanovil, že statutární orgán činí právní úkony právnické osoby, ale i z obchodního zákoníku, který rozlišoval výslovně v \13 mezi jednáním právnické osoby a zastoupením právnické osoby. Jinými slovy, právní úprava před rekodifikací soukromého práva přiznávala právnické osobě právní osobnost i svéprávnost.

Koncepční východisko nového občanského zákoníku spočívá právě na teorii fikce právnických osob. ${ }^{43}$ Tento závěr opírám o znění \ 20 odst. 1 obč. zák, který sice stanoví, že právnická osoba má právní osobnost, tj. způsobilost mít práva a povinnosti, na rozdíl od člověka se však již nijak nezmiňuje o svéprávnosti. Skutečnost, že právnická osoba svéprávná není, neplyne jen z toho, že v \20 obč. zák. jí svéprávnost není přiznána, nýbrž a zejména také z toho, že člen statutárního orgánu právnické osoby nejedná jejím jménem, nýbrž za právnickou osobu. To plyne z doslovného znění \151 odst. 1 obč. zák., podle kterého zákon stanoví, popř́ipadě zakladatelské právní jednání určí, jakým způsobem a v jakém rozsahu členové orgánů právnické osoby za ni rozhodují a nahrazují její vůli, ve spojení s \164 obč. zák., který stanoví, že člen statutárního orgánu může zastupovat právnickou osobu ve všech záležitostech.

Můžeme shrnout, že teoretická koncepce právnické osoby se rekodifikací soukromého práva zásadně změnila. Zatímco občanský zákoník z roku 1964 a obchodní zákoník považoval právnickou osobu za právní subjekt s vlastní vưlí, kterou umí samostatně svým statutárním orgánem projevovat navenek, nový občanský zákoník dává právnické osobě pouze právní osobnost, bez vlastní vưle, vưli právnické osoby nahrazují členové jejího statutárního orgánu. Krátce řečeno, zatímco koncepce právnické osoby byla v občanském zákoníku z roku 1964 a obchodním zákoníku postavena na organické teorii, v novém občanském zákoníku stojí na teorii fikce. ${ }^{44}$

42 BERAN, K. a kol. Právní jednáni a odpovédnost právnických osob po rekodifikaci soukromého práva. Praha: Wolters Kluwer ČR, 2018, s. 26.

43 ELIÁŠ, K. a kol. Nový občanský zákoník s aktualizovanou diovodovou zprávou. Praha: Sagit, 2012, s. 76-77.

44 Shodně BERAN, K. Teoretická koncepce právnických osob podle Viktora Knappa. In: Viktor Knapp: védecké dílo v proménách času. Plzeň: Vydavatelství a nakladatelství Aleš Čeněk, 2014, s. 294-308; BERAN, K. Trestní odpovědnost právnických osob z pohledu nového občanského zákoníku. Trestněprávni revue, 2014, c. 7-8, s. 179-186. 


\section{Aktuální otázka povahy odpovědnosti za jednání s péčí řádného hospodáře}

Ve světle výše uvedených úvah o koncepci právnické osoby je tedy třeba zvážit, zda je výkon funkce člena orgánu právnické osoby výkonem smluvního zastoupení nebo realizací zastoupení zákonného. V návaznosti na to se klade otázka, zda porušení povinnosti péče řádného hospodáře je porušením povinnosti smluvní či povinnosti zákonné, za nějž škůdce odpovídá v prvém případě subjektivně nebo v druhém př́ípadě objektivně. Havel společně s Štenglovou a Piherou zastávají názor, že jde o zastoupení zákonné a o zákonnou povinnost s argumentem, že chápou pozici člena orgánu jako svého druhu soukromý úrad, který je tvořen zákonem, přičemž tento úřad je následně smluvně obsazen. ${ }^{45}$ Havel s Piherou svůj názor odůvodňují tím, že: „, u]váżíme-li, že obsah požadavku péče rádného hospodáré, v̌ètně konkretizace jeho aspektù ve formè jednotlivých konkrétních povinností pri správě cizího majetku, je vymezen zákonem, mèla by být kompenzačni odpovédnost vădy subjektivni, a to i v prípadech, kdy je status správce cizího majetku založen smlouvou. "46 Dále argumentují, že tento závěr potvrzuje i znění \ 2912 odst. 2 obč. zák, který normuje předpoklad nedbalosti při neužití požadované péče, a znění \159 odst. 1 obč. zák. presumující nedbalost a tím upřesňující \ 2912 odst. 2 obč. zák.. ${ }^{47}$

Štenglová k tomu dodává, že v některých případech (např. jmenování likvidátora podle \270 odst. 1 obč. zák.), dokonce nelze mezi členem orgánu a obchodní korporací žádnou dohodu vystopovat, důsledkem čehož by bylo, že jmenuje-li soud likvidátorem člena statutárního orgánu bez jeho souhlasu (〔 191 odst. 3 obč. zák.), nemá takový likvidátor povinnost péče řádného hospodáře. ${ }^{48}$ Také další autoři se přiklánějí k názoru, že statutární orgán je zákonný zástupce právnické osoby, ${ }^{49}$ porušení povinnosti péče

45 ŠTENGLOVÁ, I. a B. HAVEL. In: ŠTENGLOVÁ, I. a kol. Zákon o obchodních korporacích. Komentár. Praha: C. H. Beck, 2013, s. 134; PIHERA, V. a B. HAVEL. Povaha funkce a odpovědnost členů orgánů obchodních společností jako východisko racionálního corporate governance. Právní roz̧bledy, 2019, č. 23-24, s. 836 a násl.

46 PIHERA, V. a B. HAVEL. Povaha funkce a odpovědnost členů orgánů obchodních společností jako východisko racionálního corporate governance. Právní roz̧bledy, 2019, č. 23-24, s. 836 a násl.

47 Ibid.

48 ŠTENGLOVÁ, I. a B. HAVEL. In: ŠTENGLOVÁ, I. a kol. Zákon o obchodních korporacích. Komentár. 2. vyd. Praha: C. H. Beck, 2017, \51 marg. č. 3.

49 DVOřÁK, T. In: ŠVESTKA, J., J. DVOŘÁK, J. FIALA a kol. Občanský zákoník. Komentár. Svazek I. Praha: Wolters Kluwer, 2014, s. 536; EICHLEROVÁ, K. In: ČERNÁ, S., S. PLÍVA a kol. Podnikatel a jeho právni və̧tahy. Praha: Univerzita Karlova, 2013, s. 17; JURÁŠ, M. Zastoupení právnické osoby v civilním právu - aktuální problémy. Právní roz̧hledy, 2014, č. 12, s. 428-432; TOMSA, M. In: ŠTENGLOVÁ, I., J. DĚDIČ a M. TOMSA. Základy obchodního práva: vysokoškolská učebnice. Praha: Leges, 2014, s. 60; ZOULÍK, F. In: DVOŘÁK, J., J. ŠVESTKA, M. ZUKLÍNOVÁ a kol. Občansképrávo hmotné. Praha: Wolters Kluwer, 2013, s. 277; NOVOTNÁ KRTOUŠOVÁ, L. Následky konfliktu zájmů člena statutárního orgánu právnické osoby jako zástupce a právnické osoby jako zastoupeného. Právní roz̧bledy, 2016, č. 7, s. 588-595; ČECH, P. Rekodifikace: hlavní změny v právu společností. Právní rádce, 2012, č. 5, s. 7 a násl., byt' u něj došlo následně k názorovému posunu ve propěch zastoupení sui generis. 
řádného hospodáře je porušením povinnosti zákonné, za nějž škůdce odpovídá subjektivně. ${ }^{50}$

Kompromisní řešení přinesl Svoboda, který jednání právnické osoby považuje za specifickou formu prímého zastoupení na pomezí mezi zákonným a smluvním zastoupením ${ }^{51}$ a argumentuje, že statutární orgány a do jisté míry i způsob jejich právního jednání jménem právnické osoby vymezuje zákon, avšak své postavení získávají na základě zakládajícího dokumentu právnické osoby, prrípadně na podkladu rozhodnutí valné hromady. Jednání statutárního orgánu za právnickou osobu jako zastoupení sui generis taktují i další autoři. ${ }^{52}$ Koncepce zastoupení svého druhu se nakonec prosadila i v aktuální judikatuře. Vrchní soud v Praze v usnesení ze dne 4. 8. 2015, sp. zn. 14 Cmo 184/2014, publikovaném pod č. 42/2016 Sbírky soudních rozhodnutí a stanovisek, uvedl, že ,jednatelské oprávnèni statutárníbo orgánu má základ v zakladatelském jednáni a jmenováni (volbè) do funkece a jednatelské oprávnèni statutárníbo orgánu je podle $\int 164$ odst. 1 o. ₹. neomezené. Právni úprava účinná od 1. 1. 2014, jak je patrné z citovaného \} 1 6 4 \text { odst. 1, } 2 \text { o. z:, stoji nově na tom, že člen } statutárníbo orgánu jedná jako zástupce právnické osoby sui generis (nejedná se o zastoupení zákonné ani o zastoupeni smluvní). " $\mathrm{Na}$ tuto tezi navázal a dále ji rozvedl Nejvyšší soud v rozsudku ze dne 23. 7. 2019, sp. zn. 27 Cdo 4593/201, publikovaným pod č. 4421/2019 Sbírky soudních rozhodnutí a stanovisek: „Jakkoliv je vatah mezi členem statutárního orgánu a právnickou osobou, o jejiž orgán jde, vątahem smluvním (vzniké na základě soublasného projevu vůle právnické osoby a dotčeného člena), rozsah zástupč̉ho oprávnèní je primárnè upraven zákonem a v jeho

50 DVOŘÁK, T. In: ŠVESTKA, J., J. DVOŘÁK, J. FIALA a kol. Ob̌́anský zákoník. Komentářr. Svazeke I. Praha: Wolters Kluwer, 2014, s. 531; HÁMORSKÁ, A. Povinnost členů orgánů obchodních korporací jednat s péći řádného hospodáře po rekodifikaci. Obchodněprávni revue, 2012, č. 9, s. 250 a násl.; BORSíK, D. Péče řádného hospodáŕe a pravidlo podnikatelského úsudku bez legend. Obchodnéprámní revue, 2015, č. 7-8, s. 193 a násl.; NOVOTNÁ KRTOUŠOVÁ, L. Následky konfliktu zájmů člena statutárního orgánu právnické osoby jako zástupce a právnické osoby jako zastoupeného. Právní roz̧bledy, 2016, č. 7, s. 588-595; neprímo dovozuje BORKOVEC, A. Právní následky porušení fiduciárních povinností. Práuní roz̧ledy, 2020, č. 4, s. 121 a násl.

51 SVOBODA, K. In: ŠVESTKA, J., J. DVOŘÁK, J. FIALA a kol. Občanský zákoník. Komentár. Svazeek I. Praha: Wolters Kluwer, 2014, s. 1037; HÁMORSKÁ, A. Povinnost členů orgánů obchodních korporací jednat s péći řádného hospodáře po rekodifikaci. Obchodnèprávní revue, 2012, č. 9, s. 250 a násl.

52 DĚDIČ, J. Úprava konfliktů zájmů v zákoně o obchodních korporacích ve vazbě na nový občanský zákoník. Práuni roz̧ledy, 2014, č. 15-16, s. 524 a násl.; LASÁK, J. In: LAVICKÝ, P. a kol. Občanský zákoník I. Obecná cást. (J 1-654). Komentár. Praha: C. H. Beck, 2014, s. 843; ZUKLÍNOVÁ, M. In: DVOŘÁK, J., J. ŠVESTKA, M. ZUKLÍNOVÁ a kol. Občanské právo hmotné. Praha: Wolters Kluwer, 2013, s. 313; ČECH, P. a P. ŠUK. Právo obchodnich společnosti: v praxi a pro praxi (nejen soudni). Praha: Ivana Hexnerová Bova Polygon, 2016, s. 21 a 22; pozice Tichého není zcela jednoznačná, protože sice pro smíšenou povahu tohoto zastoupení argumentuje, dále však operuje se zastoupením zákonným, srov. TICHÝ, L. Obecná cáast občanskébo práva. Praha: C. H. Beck, 2014, s. 342 a násl.; Melzer, který také pléduje pro smíšenou povahu zastoupení právnické osoby, současně upřednostňuje analogii se zastoupením smluvním, srov. MELZER, F. In: MELZER, F. a kol. Občanský zákoník: velký komentár. Svazek III. \419-654 a souvisejicí společná a prechodná ustanovení. Praha: Leges, 2014, s. 45; čistě smluvní povahu tohoto zastoupení hájí POKORNÁ, J. In: ŠVESTKA, J., J. DVOŘÁK, J. FIALA a kol. Občanský zákonik. Komentár. Svazeke I. Praha: Wolters Kluwer, 2014, s. 1089. 
mezich zakiladatelským právním jednánim (srov. diovody R 10/2019). Clena statutárního orgánu nelže považovat za żmocnènce právnické osoby (jednajicíbo na základě plné moci), ale ani za typickébo zákonnébo zástupce či dokonce opatrovníka právnické osoby. S obledem na specifika postaveni člena statutárníbo orgánu se Nejvyšsi soud kloni k závèru, že nejde ani o zástupce smluvního, ani o zástupce zákonnébo. Zastoupení členem statutárního orgánu je zastoupením svébo drubu (sui generis), na něž nedopadá ani úprava smluvního zastoupeni (』 441 až 456 o. ₹.), ani úprava zastoupení zákonnébo (I 457 až 488 o. z.)."

S koncepcí porušení péče řádného hospodáře jako porušením smluvní povinnosti ve smyslu \2913 obč. zák. přišel první Lasák, který svůj názor odůvodňuje tak, že vznik funkce člena statutárního orgánu na základě volby, jmenování či jiného povolání do funkce dle \ 152 odst. 2 obč. zák. je v prvé řadě zvláštním důvodem uzavření smlouvy mezi tímto členem statutárního orgánu a obchodní korporací. Smluvní povahu dovozuje z formulace $\int 159$ odst. 1 obč. zák., který uvádí, že kdo přijme funkci člena statutárního orgánu, zavazuje se, že ji bude vykonávat s péčí řádného hospodáře. Ze skutečnosti, že o výkonu funkce bude pravidelně uzavřena smlouva, Lasák dovozuje, že není žádného důvodu, aby porušení těchto výslovně stanovených smluvních povinností mělo mít z hlediska náhrady škody odlišný režim proti porušení péče řádného hospodáře, která je imanentní součástí smluvního vztahu mezi obchodní korporací a členem statutárního orgánu, který je $\mathrm{v}$ důsledku vzniku funkce založen. ${ }^{53} \mathrm{I}$ další autoři se kloní $\mathrm{k}$ názoru, že $\mathrm{v}$ př́ípadě péče řádného hospodáře jde o povinnost smluvní a že její porušení vede k objektivní odpovědnosti, tedy k povinnosti nahradit tím způsobenou škodu podle \ 2913 obč. zák. s možností liberace..$^{54}$

Lze shrnout, že za předpokladu, že se autoři vyjadřují k oběma otázkám, platí, že ti z nich, kdo považují člena statutárního orgánu za zákonného zástupce právnické osoby, vnímají porušení povinnosti péče řádného hospodáře za porušení zákonné povinnosti, tedy upřednostňují statusový charakter vztahu právnické osoby a člena statutárního orgánu a dovozují subjektivní odpovědnost. ${ }^{55}$ Autoři, kteří považují člena statutárního orgánu za zástupce smluvního či sui generis, posuzují porušení povinnosti péče řádného hospodáře

53 LASÁK, J. In: LASÁK, J., J. POKORNÁ, J. ČÁP a T. DOLEŽIL. Zákon o obchodních korporacích. Komentár. Dí. I. Praha: Wolters Kluwer, 2014, s. 413; shodně HOUDEK, Z. Nad charakterem porušení fiduciárních povinností člena voleného orgánu. Časopis pro právni vědu a praxi, 2016, č. 4, s. 541 a násl.

54 ČECH, P. a P. ŠUK. Právo obchodnich společností v praxi a propraxi (nejen soudní). Praha: Ivana Hexnerová - Bova Polygon, 2016, s. 174; ŠUK P. In: ŠTENGLOVÁ, I. a kol. Zákon o obchodnich korporacích. Komentár. 2. vyd. Praha: C. H. Beck, 2017, \51 marg. č. 3; BEZOUŠKA, P. a L. PIECHOWIZOVÁ. Nový obćanský zákoník. Nejduiležitějjši żmény. Olomouc: ANAG, 2014, s. 49; PELIKÁN, R. a I. PELIKÁNOVÁ. In: ŠVESTKA, J., J. DVOŘÁK, J. FIALA a kol. Občanský zákoník. Komentár. Svaẓek I. Praha: Wolters Kluwer, 2014, s. 1017.

55 DVOŘÁK, T. In: ŠVESTKA, J., J. DVOŘÁK, J. FIALA a kol. Občanský zákoník. Komentár. Svazek I. Praha: Wolters Kluwer, 2014, s. 531 a 536; ŠTENGLOVÁ, I. a B. HAVEL. In: ŠTENGLOVÁ, I. a kol. Zákon o obchodních korporacích. Komentár. 2. vyd. Praha: C. H. Beck, 2017, \51 marg. č. 3; NOVOTNÁ KRTOUŠOVÁ, L. Následky konfliktu zájmů člena statutárního orgánu právnické osoby jako zástupce a právnické osoby jako zastoupeného. Právní roz̧bledy, 2016, č. 7, s. 595. 
jako porušení smluvní povinnosti, a tedy upřednostňují smluvní charakter vztahu právnické osoby a člena statutárního orgánu a dovozují objektivní odpovědnost. ${ }^{56}$

Při posouzení, o jaký druh zastoupení jde, je třeba vycházet z teoretického vymezení smluvního a zákonného zastoupení a z teorie fikce právnických osob, na které stojí koncepce právnické osoby v občanském zákoníku. Také je možné se opřít o komparaci s německým právním řádem. Smluvní zastoupení předpokládá uzavření dohody o zastoupení mezi zástupcem a zastoupeným o tom, že zástupce získává právní možnost jednat jménem zastoupeného s přímými účinky pro něj. ${ }^{57}$ Vznik smluvního zastoupení je tedy plně projevem autonomie vůle zástupce a zastoupeného v otázkách, zda zastoupení vznikne, jaké bude mít zástupce oprávnění a kdo bude zástupcem. Naopak zákonné zastoupení není projevem vưle zastoupeného, jde o př́pady, kdy zastoupený má právní osobnost, ale nemá právně relevantní vưli, kterou by mohl právně relevantně projevit, ${ }^{58}$ jinými slovy, není svéprávný. Soudím, že klíčový rozdíl mezi smluvním zástupcem a zákonným zástupcem tkví v tom, že svéprávný zastoupený má možnost volby, zda bude nebo nebude mít smluvního zástupce. Naopak nesvéprávný zastoupený zákonného zástupce mít musí, protože nemá-li jej, není schopen právně relevantně tvořit vưli a projevovat ji navenek, tedy autonomie na straně zastoupeného, zda si zákonného zástupce vůbec zvolit, dána není. Jinými slovy, nesvéprávný zastoupený zákonným zástupcem může mít vliv na to, kdo bude jeho zákonným zástupcem, ale nemá vliv na to, zda jej mít musí či nemusí.

Podle fikční teorie právnická osoba nemá vlastní vưli, ale je jí přičítána vưle členů jejích orgánů, tedy vůle osob za ni jednajících, přičemž zákon stanoví, poprrípadě zakladatelské právní jednání určí, jakým způsobem a v jakém rozsahu členové orgánů právnické osoby za ni rozhodují a nahrazují její vůli. Lze tedy říci, že podle fikční teorie právnická osoba není svéprávná, čemuž odpovídá i uvedená konstrukce právnické osoby v občanském zákoníku. Není-li právnická osoba svéprávná, musí mít zákonného zástupce, který její vưli vytváří a projevuje navenek. Orgán, který tvoří vưli právnické osoby a projevuje ji navenek, je statuární orgán právnické osoby, resp. jeho členové. Z toho dovozuji, že člen statutárního orgánu je zákonným zástupcem právnické osoby.

Názory, které plédují pro to, aby zastoupení právnické osoby členem statutárního orgánu bylo považováno za zastoupení smluvní, operují s argumentem, že funkce člena statutárního orgánu vzniká jmenováním do funkce a přijetím této funkce, tedy oboustranně dobrovolně. Směšují však pojmy statutárního orgánu, člena statutárního orgánu a jeho funkce v něm a zaměňují tak dobrovolnost výběru personálního obsazení funkce člena

56 LASÁK, J. In: LASÁK, J., J. POKORNÁ, J. ČÁP a T. DOLEŽIL. Zákon o obchodních korporacích. Komentár. Díl. I. Praha: Wolters Kluwer, 2014, s. 313 a 413; ČECH, P. a P. ŠUK. Právo obchodních společností v praxi a pro praxi (nejen soudní). Praha: Ivana Hexnerová - Bova Polygon, 2016, s. 21 a 174.

57 MELZER, F. In: MELZER, F. a kol. Občanský quákoník: velký komentár. Svazeke III. \419-654 a souvisejicí spolećná a prechodná ustanovení. Praha: Leges, 2014, s. 43.

58 Ibid. 
statutárního s autonomií vytvoření statutárního orgánu. Existence statutárního orgánu je jedním z pojmových znaků právnické osoby jako subjektu práva, právnické osobě není dána autonomie rozhodnutí, zda statutární orgán bude či nebude zř́zený. Pokud jej nemá zrrízený, není subjektem práva, naopak pokud v právnické osobě není obsazena funkce člena statutárního orgánu, má možnost ingerovat soud, ale v žádném př́ípadě to nemá vliv na její právní osobnost.

U autorů, kteří argumentují pro zastoupení sui generis a smluvní povahu povinnosti péče řádného hospodáře, lze vidět tendenci př́iklonu $\mathrm{k}$ organické teorii právnické osoby na základě argumentace komparací s vývojem německé doktríny a jejich snaha otevřít pro obdobný doktrinální a judikaturní vývoj dveře i v našem prostředí. ${ }^{59}$ Německý občanský zákoník v \26 odst. 1 BGB výslovně stanoví, že spolek musí mít představenstvo a že představenstvo zastupuje spolek před soudem i mimo soud a má postavení zákonného zástupce. Převládající názor německé teorie zní, že formulace „má postavení“ místo ,je“" signalizuje vůli zákonodárce ponechat dogmatický spor mezi teorií reality a fikce nerozhodnutý. Kvưli větší vhodnosti při vyplňování mezer v zákoně se dnes $\mathrm{v}$ německé doktríně prosadila teorie reality. ${ }^{60}$ Převládající názor německých komentátorů zní, že jelikož spolek, sám o sobě nezpůsobilý jednat, nabývá způsobilost k jednání až skrze představenstvo a skrze představenstvo jedná, označuje se představenstvo jako orgán. Představenstvo dle tohoto názoru tudíž není zákonným zástupcem spolku, nýbrž účastní se jako orgán spolku právního styku. Jednání představenstva není jednáním za spolek, nýbrž vlastní jednání spolku. ${ }^{61} \mathrm{~V}$ Německu se pro svéprávnost právnické osoby argumentuje prosazením organické teorie na základě jazykového argumentu, úmyslu zákonodárce a teleologického argumentu vhodnosti pro vyplňování mezer. Soudím, že jazykový argument není přenosný do českého právního prostoru. Německý zákonodárce se vyjádřil obezřretně, že představenstvo má postavení zákonného zástupce. Český zákonodárce se při popisu postavení člena statutárního orgánu vyjádřil explicitně, že člen statutárního orgánu zastupuje právnickou osobu ve všech záležitostech (\164 odst. 1 obč. zák.) a zastupuje-li právnickou osobu člen jejího orgánu (\162 obč. zák.), spojuje právo se zastoupením určité následky. Použijeme-li slova německé teorie člen statutárního orgánu ,je“ zástupcem právnické osoby, nikoliv že „má postavení zástupce a ve skutečnosti by mohl být něčím jiným.

59 ČECH, P. a P. ŠUK. Právo obchodnich společností v praxi a pro praxi (nejen soudní). Praha: Ivana Hexnerová Bova Polygon, 2016, s. 21 a 22; ČECH, P. Ke svéprávnosti právnické osoby a postavení člena statutárního orgánu při jednání za ni (nejen) v situaci zájmového střetu. Právni roz̧ledy, 2016, č. 23-24, s. 835-839; již citovaný rozsudek Nejvyššího soudu ze dne 23. 7. 2019, sp. zn. 27 Cdo 4593/2017, pochází ze soudního oddělení 27, jehož členenem je vedle JUDr. Marka Doležala a JUDr. Filipa Cilečka i JUDr. Petr Šuk.

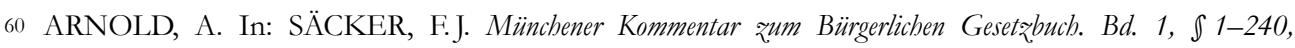
Allgemeniner Teil, ProstG, AGG. 7. vyd. München: C. H. Beck, 2015, \26 marg. č. 11.

61 SCHÖPFLIN, M. In: BAMBERGER, G., H. ROTH a kol. Beck'scher Online-Kommentar BGB. 46. vyd. München: C. H. Beck, 2018, \ 26 marg. č. 1. 
$\mathrm{V}$ českém prostředí neuspěje, myslím, ani argument vưlí zákonodárce ponechat spor teorií na doktríně. Německý zákonodárce svou vůli vyjádřil jasně v tzv. protokolech k BGB ve smyslu, že formulací, že představenstvo „má postavení“ zákonného zástupce, chce vyjádřit, že „rozhodnutí otázky konstrukce, zda právnická osoba je svéprávná bytost a proto se ve styku projevuje svými orgány, nebo zda je nesvéprávná a proto potrébuje zastoupení, ponechává vědě" "62 zatímco z formulace $\ 26$ odst. 1 BGB je zřejmé, že zůstávají zachovány přednosti koncepce zákonného zastoupení pro konstrukci zástupčího oprávnění představenstva. ${ }^{63}$ Český zákonodárce se o více než 100 let později vyjádřil v důvodové zprávě explicitně pro teorii fikce formulací, že občanský zákoník ,odlišuje nabliženi práva na lidi jako fyz̧ické osoby a na právnické osoby jako na útvary umèlé (fiktivni) ".64 Ve shodě s touto koncepcí musí zákon právnickou osobu, aby se stala subjektem práv, za takovou konstituovat a prohlásit. Občanský zákoník odmítá atropologizaci právnických osob a bere za své hledisko, že právnické osoby jsou umělé lidské útvary. ${ }^{65}$ Zároveň občanský zákoník v $\int 2$ odst. 2 stanoví, že zákonnému ustanovení nelze přikládat jiný význam, než jaký plyne z vlastních slov v jejich vzájemné souvislosti a z jasného úmyslu zákonodárce.

Třetí argument $z$ německé doktríny pro organickou teorii - vhodnost pro zaplňování mezer v zákoně - dle mého názoru neuspěje také. Podle převládající německé doktríny lze pomocí organické teorie bez složitější myšlenkové konstrukce vysvětlit, že právnická osoba prostřednictvím svých orgánů může vědět, chtít (tj. mít vưli) a jednat. ${ }^{66}$ Každým obrazným znázorněním bez složitější myšlenkové konstrukce se nutně dostáváme do rizika př́lišného zjednodušení problému. Dle mého názoru německá koncepce přináší s sebou těžko překonatelný vnitřní rozpor. Pokud považujeme jednání členů statutárního orgánu za jednání právnické osoby, tedy pokud právnická osoba jedná sama skrze svůj statutární orgán, jak může být zároveň při tomto samostatném jednání zastoupena jinou osobou (tj. členem statutárního orgánu)? Pojmově se vlastní jednání osoby a zastoupení osoby ve stejné věci vylučují. Podle organické teorie jedná právnická osoba svými orgány, které mají postavení zákonných zástupců, ale podle právní úpravy zastoupení může zástupce být pouze svéprávná osoba, což statutární orgán není. Podle organické teorie jednatelské oprávnění náleží statutárnímu orgánu. V českém právu je v souladu s teorií fikce jednatelské oprávnění spojeno až s funkcí člena statutárního orgánu, právě aby byl překlenut zmíněný rozpor obsažený v německém právu.

Jádro nastíněného sporu spočívá v otázce, zda vztah člena statutárního orgánu a právnické osoby je pouhým vztahem smluvním či vztahem statusovým - týkajícím se práva

62 MUGDAN, V. (Hrsg.). Die gesßammten Materialien zum Bürgerlichen Gezetz̧buch für das Deutsche Reich. I. band. Einführungsgesetz und Allgemeniner Theil. Berlin: R.v. Decker's Verlag, 1899, s. 609.

63 Ibid.

64 ELIÁŠ, K. Nový občanský qákoník s aktualizovanou di̊vodovou zprávou a rejstř́kem. Ostrava: Sagit, 2012, s. 76.

65 Ibid., s. 77.

66 BEUTHEIN, V. Gibt es eine organschaftliche Stellvertretung? Neue Juristische Wochenschrift, 1999, s. 1142 a násl. 
postavení právnické osoby. Tato otázka nabývá na významu i v souvislosti s určením, zda se $\mathrm{v}$ př́padě povinností péče řádného hospodáře jedná o úpravu kogentní či dispozitivní ve smyslu $\int 1$ odst. 2 obč. zák. Pro zodpovězení otázky je třeba dle mého soudu rozlišovat pojem orgánu, statutárního orgánu, funkci člena statutárního orgánu a osobu (fyzickou či právnickou), která funkci člena statutárního orgánu vykonává.

Z hlediska normativní teorie je osoba (at' právnická, tak fyzická) bod přičitatelnosti, což znamená, že právní řád tedy přičítá osobě zpơsobilost být povinnostním subjektem, být subjektem práva a být subjektem oprávnění, resp. dovolení, stanovit jiné osobě povinnost. ${ }^{67}$ Beran se však domnívá, že z ," ,praktických' divodů je nutné každému bodu pričitatelnosti pričitat také rozum a villi jako nezbytné predpoklady pro to, aby práva a povinnosti mobly být realizovány ve vnèjš̀m svèté" 68 Je však otázkou, čí rozum a vůle se právnické osobě jako bodu přičitatelnosti přičítá. Savigny konstatuje o právnické osobě, že ,jeji reálná existence spočivá v zástupči viili jednotlivých osob, keterá ji je na základě fikece pricútána jako jeji vlastni vile ".69 Jak argumentuje Beran, z právně analytického hlediska rozum a vůle právnické osoby je cizím rozumem a vưlí, které jako vlastní rozum a vưle mohou náležet pouze konkrétní svéprávné fyzické osobě. Přičítání cizího rozumu a vůle je v př́ípadě právnické osoby bezvýjimečné. Právnická osoba je tak vždy závislá na jiné svéprávné fyzické osobě, jejǐž rozum a vưle jí musejí být přičítány. ${ }^{70}$

Podle $\int 151$ odst. 1 obč. zák. zákon stanoví, popřípadě zakladatelské právní jednání určí, jakým způsobem a v jakém rozsahu členové orgánů právnické osoby za ni rozhodují a nahrazují její vůli. Podle \ 152 odst. 1 obč. zák. si právnická osoba tvoří orgány o jednom či více členech. Orgán právnické osoby je tedy právnickou osobou vytvořený soubor působnosti náležející osobě či osobám, které za právnickou osobu rozhodují a nahrazují její vůli, přričemž člen orgánu je osoba, která vykovává tuto působnost. ${ }^{71}$ Statutární orgán je tedy soubor tzv. zbytkové působnosti, tedy působnosti, kterou zakladatelské právní jednání, zákon nebo orgán veřejné moci nesvěřil jinému orgánu právnické osoby (『 163 obč. zák.). Člen statutárního orgánu je osoba, která př́ijme funkci ve statutárním orgánu a vykonává tuto zbytkovou působnost.

Funkce člena statutárního orgánu je tvořena dvěma aspekty. Zaprvé dílčím výsekem ze souboru působnosti tvořící statutární orgán, který připadá na osobu, která funkci člena statuárního orgánu vykonává. Jinými slovy funkce člena statutárního orgánu je rozhodovat a nahrazovat vưli právnické osoby na tomto dílčím výseku ze souboru působnosti tvořící statutární orgán (\$ 151 odst. 1 obč. zák). Za druhé funkce člena statutárního

67 BERAN, K. Osoba jako „bod prričitatelnosti“. Právník, 2017, č. 6, s. 519.

68 Ibid., s. 520.

69 SAVIGNY, F. C. von. System des heutigen Römischen Rechts. Zweyter Band. Berlin: Veit \& Comp., 1840, s. 312.

70 BERAN, K. a kol. Právní jednáni a odpovédnost právnickéch osob po rekodifikaci soukromébo práva. Praha: Wolters Kluwer ČR, 2018, s. 31.

71 WOLFF, H. J. Organschaft und juristische Person. Bd. 2. Aalen: Scientia-Verlag, 1968, s. 224. 
orgánu je zastupovat samostatně právnickou osobu navenek ve všech záležitostech, neurčí-li zakladatelské právní jednání jinak (『 164 obč. zák.). Takto široce pojatou funkci občanský zákoník nedovoluje vykonávat libovolně, s funkcí občanský zákoník spojuje povinnost vykonávat ji s péćí rádného hospodáře (\$ 159 odst. 1 obč. zák.).

Funkcí člena statutárního orgánu je tedy soubor působnosti a povinností ve vzájemné souvztažnosti sestávající z práva vytvářet vưli přičítanou právnické osobě, práva projevovat za právnickou osobu tuto vưli navenek a povinnosti činit obojí s péčí ráádného hospodáře. $\mathrm{V}$ české právní teorii je vedena diskuze o tom, zda a do jaké míry je úprava působností orgánů právnických osob kogentní. Někteří autoři zde spatrujuí velký prostor pro smluvní autonomii, ${ }^{72}$ jiní plédují pro statusovost a tedy kogentnost této úpravy. ${ }^{73}$ Lze však najít minimální společný jmenovatel mezi zastánci obou táborů, a sice panuje shoda na tom, že kogentní je úprava „stěžejni minimálni kompetenčni struktury povinných orgánů právnické osoby súcelem zachováni predpokládaného odlišeni statutárních a jiných orgánu právnické osoby “74 Vzhledem k úzkému propojení práv spojených s funkcí člena statutárního orgánu s povinností péče řádného hospodáře $\mathrm{v}$ rámci výkonu funkce člena statutárního orgánu soudím, že povinnost péče řádného hospodáře je také statusovou záležitostí právnické osoby. ${ }^{75}$ Proto považuji porušení povinnosti péče řádného hospodáře př̀i výkonu funkce člena statutárního orgánu za porušení zákonné povinnosti podle \2910 obč. zák.

\section{Závěr}

Cílem tohoto článku je zodpovědět otázku, zda se v př́padě odpovědnosti za jednání s péči řádného hospodáře jedná o odpovědnost subjektivní, či odpovědnost objektivní. Pro pochopení jádra sporu o koncepci odpovědnosti, který se v české doktríně vede, je nejprve třeba připomenout právní úpravu odpovědnosti členů statutárních orgánů obchodních společností před rekodifikací soukromého práva a dále je treba nastínit

72 HURDÍK, J. Kogentnost a dispozitivnost ustanovení nového občanského zákoníku o právnických osobách. Ke vzájemné použitelnosti ustanovení o nadacích a nadačních fondech. Právní roz̧hledy, 2014, č. 7, s. 233; HAVEL, B. Úvahy ke statusovým limitům smluvní podstaty korporace. Právny ob₹or, 2014, č. 4, s. 379; RONOVSKÁ, K. a B. HAVEL. Kogentnost úpravy právnických osob a její omezení autonomiî vůle, nebo vice versa? Obchodnéprávní revue, 2016, č. 2, s. 33 a násl; RONOVSKÁ, K. Spolková autonomie v novém soukromém právu: její význam a limity. Právní roz̧hledy, 2016, č. 4, s. 115 a násl.

73 MELZER, F. a P. TÉGL. In: MELZER, F. a kol. Občanský quákoník: velký komentár. Svazek I. $\int 1-117$. Praha: Leges, 2013, s. 63; PELIKÁNOVÁ, I. a R. PELIKÁN. In: LAVICKÝ, P. a kol. Občanský zákoník I. Obecná ćást. (』 1-654). Komentár. Praha: C. H. Beck, 2014, s. 16.

74 RONOVSKÁ, K. a B. HAVEL. Kogentnost úpravy právnických osob a její omezení autonomií vưle, nebo vice versa? Obchodněprávní revue, 2016, č. 2, s. 33 a násl.

75 Shodně RONOVSKÁ, K. Spolková autonomie v novém soukromém právu: její význam a limity. Právní roz̧bledy, 2016, č. 4, s. 115 a násl; pro kogentnost úpravy péče řádného hospodáře HAVEL, B. Výkon funkce člena statutárního orgánu, vč. smlouvy o výkonu funkce v prolnutí ZOK a OZ. Karlovarské právnické dny 2014. Sborník. Praha: Leges, 2014, s. 416. 
dopady rekodifikace soukromého práva do oblasti právní úpravy postavení členů statutárních orgánů a jejich odpovědnosti. Dobově převládalo pojetí, že vztah mezi členem statutárního orgánu a obchodní společností má povahu absolutního obchodního závazkového vztahu dle \261 odst. 3 písm. f) obch. zák. Podle úpravy obchodního zákoníku nebylo třeba řešit problém, zda jde o subjektivní nebo objektivní odpovědnost, jednak proto, že se takto neodlišovalo mezi porušením smlouvy a zákona, a jednak i pro dikci $\int 757$ obch. zák., který porušení zákona vždy podřazoval porušení smlouvy. Odpovědnost za porušení péče řádného hospodáře ve svém dobovém sankčním pojetí byla povinností objektivní, tedy neuplatnilo se zde hledisko zavinění, byla však k dispozici liberace. Na jiné typy právnických osob než kapitálové obchodní společnosti se ovšem úprava v obchodním zákoníku aplikovat př́mo nedala.

Rekodifikace přinesla do oblasti právní úpravy postavení členů statutárních orgánů a jejich odpovědnosti řadu výrazných změn. Právnická osoba není schopna sama právně jednat, a zákon proto předpokládá, že vưli za ni nahrazují její orgány (〔 151 odst. 1 obč. zák.). Zákon dále stanoví, že za právnickou osobu jednají zpravidla její statutární orgány, a to jako zástupci (\436 a násl. obč. zák.), nikoliv jako nástroje př́mého jednání samotné právnické osoby. Smyslem péče řádného hospodáře není, aby vznikla odpovědnost za její porušení, nýbrž naopak aby se osoby v pozici, kdy je jim tato povinnost uložena, chovaly tak, aby jejich odpovědnost nevznikla. Jinými slovy, jde o pojetí, které nestojí na sankční koncepci odpovědnosti, nýbrž se jedná o prospektivní koncepci odpovědnosti, jakožto odpovědnosti, která se realizuje tím, že se osoba chová řádně, tj. v souladu s požadavky, které jsou na ni kladeny v návaznosti na výkon její funkce. Koncepce odpovědnosti za jednání s péči řádného hospodáře je založena na obecné úpravě povinnosti k náhradě škody. Občanský zákoník opustil doktrínu jednotného civilního deliktu a upravuje odlišný režim odpovědnosti za jednání v rozporu se zákonnou povinností v \} 2 9 1 0 \text { a násl. obč. zák. či smluvní povinností v \} 2 9 1 3 \text { a násl. obč. zák. }

Zastávám tezi, že pro vyřešení problému konstrukce soukromoprávní odpovědnosti za jednání s péčí řádného hospodáře je třeba se nejdříve zabývat otázkami, jak právnická osoba jedná, jak je jednání právnické osoby ovlivněno teoriemi právnických osob a jakým způsobem se teorie právnických osob projevují v platné právní úpravě. Rekodifikace soukromého práva změnila teoretickou koncepci právnické osoby v českém právu. V občanském zákoníku z roku 1964 a obchodním zákoník byla právnická osoba považována za právní subjekt s vlastní vůlí, kterou může samostatně svým statutárním orgánem projevovat navenek, což odpovídá teoretické koncepci právnické osoby postavené na organické teorii. Ve stávajícím občanském zákoníku je právnická osoba konstruována jako právní subjekt bez vlastní vưle, vưli právnické osoby nahrazují členové jejího statutárního orgánu, tedy v novém občanském zákoníku stojí teoretická právnické osoby na teorii fikce. Tato úvaha je důležitá při zodpovězení otázky, jaký odpovědnostní režim budou mít členové statutárních orgánů za porušení povinnosti 
jednat s péči řádného hospodáře. V prrípadě, že člen statutárního orgánu má postavení zákonného zástupce, lze uvažovat o tom, že povinnosti, které se na něj vztahují, jsou dány zákonem, a tedy i jejich porušení lze subsumovat pod zákonnou odpovědnost založenou na subjektivním principu. $\mathrm{V}$ prípadě, že budeme považovat člena statutárního orgánu zástupce na základě smlouvy či zástupce sui generis, potom lze uvažovat o tom, že odpovědnost za jednání s péčí rádného hospodáře podřadíme pod smluvní režim odpovědnosti, za kterou se odpovídá objektivně.

Klíčový rozdíl mezi smluvním zastoupením a zákonným zastoupením tkví v tom, že svéprávný zastoupený má možnost volby, zda bude nebo nebude mít smluvního zástupce. Naopak nesvéprávný zastoupený zákonného zástupce mít musí, protože nemá-li jej, není schopen právně relevantně tvořit vưli a projevovat ji navenek. Z toho dovozuji, že zastoupení právnické osoby členem statutárního orgánu je zastoupením zákonným, proto i odpovědnost za jednání s péči řádného hospodáře bude sankcionováno povinností k náhradě škody za porušení zákonné povinnosti dle \2910 obč. zák. 